\title{
Awareness about and Implementation of Research Findings on Mathematics Education among Teachers in Selected Schools in Ibadan, Nigeria
}

\author{
Samson Sunday Afolabi ${ }^{1}$ \\ ${ }^{1}$ Department of Science Education, Faculty of Education, National Open University of Nigeria \\ [*E-mail: safolabi@noun.edu.ng]
}

\begin{abstract}
This study attempted to establish the level of awareness about and implementation of research findings in some aspects of Mathematics Education. Two validated instruments (on teachers' awareness about and their use of research findings) were used to collect data from 132 mathematics teachers who had been purposively selected from a random sample of 34 secondary schools in Ibadan metropolis. The findings were that Mathematics teachers are moderately aware of research findings on Mathematics education. There were significant differences between teachers' qualifications in Mathematics and use of research findings on Mathematics testing. Motivation of Mathematics teachers to explore new strategies of teaching and to implement them in their classroom practice is recommended.
\end{abstract}

Keywords: Mathematics education; Research utilisation; STEM.

\section{$1 \quad$ Introduction}

Research is a way of logical search for information in order to accomplish a task and present it in a comprehensible form (EduBirdie, 2016). When an individual is confronted by a situation or question to which he could not find a ready answer or solution, he seeks to find out by investigation, ask questions, analyse situations, sorts and probably make inference. He is carrying out research in this process. Every one probably perform research in everyday life (M. Libraries, $n d$ ). In majority of instances, research is not meant to be just for its own sake. Rather, it is directed at solving problems in human lives and society. According to Edubirdie (2016), people carry out research in order to share their ideas, or in order to increase their understanding of challenging topics. 
There are many reasons why a particular research is carried out. Most importantly is the concern for problem solving. There are many researches and one may almost be right to say that they are unlimited. Therefore, it becomes necessary to consider the research that aims at solving particular problems at any point in time.

However, studies on how research findings are implemented are not common. There are several aspects of mathematics education in which research have been carried out. Afolabi (2017) studied on the practical approach to teaching and assessment in mathematics. The study was an exposition and confirmation that some aspects of mathematics could be taught through practical approach and as well tested through practical approach. His respondents comprised mathematics teachers, mathematics educators and educationist of many years' experience. The findings showed that it was generally believed that mathematics can be taught practically but it was an opinion of the few that it can be assessed practically. A lot of research on teaching methods and their effects on students' achievement in mathematics abound. These include the study by Ogunbiyi (2004), Douville (2004), Douville and Pugalee (2003), Abimbade and Afolabi (2012).

The direction of these studies include the search of methods commonly used by teachers and rationale for the choice of methods (Afolabi, 2010). This also includes the effects of teaching methods on learning outcomes. Another area of research in mathematics education is research on mathematics textbook which is an unpopular area in mathematics education research. However, it is gaining attention gradually. The authors on mathematics textbooks include Afolabi (2015), Afolabi and Animasahun (2013), Gharbavi and Mousavi (2012), Do (2010) and Johannson (2003). Researches on this area include use of mathematics textbooks, gender representation in mathematics textbooks and mathematics textbook analysis. Another aspect of research in mathematics education is that which bothers on school environment, school leadership and mathematics achievement. This include the work of Omisakin (2018). One of the trends of research in mathematics education is the place of social media and ICT in learning mathematics. Durodola (2017) considered the effect of mobile learning on Trigonometry. He concluded from his findings that students exposed to mobile learning achieved better than their colleagues exposed to conventional method.

Teachers are often exposed to more and new teaching strategies as they go further in the in-service training. It is expected that teachers of higher qualifications are exposed to more and new teaching methods. As a teacher moves from first degree to master's degree, he is expected to be more exposed to new methods and research findings and implementations as his new carrier will bring about these opportunities and exposures. This is not just attainment of a higher degree. Rather, more relevant awareness about research findings and its 
implementation in classroom practice occurs if the teacher attains higher degree in mathematics education.

In the application of research findings, a prominent scale was developed by Funk, Champagne, Wiese and Tornquist (1991) and was reviewed among other scales by Kajermo, Bostrom, Thompson, Hutchinson, Estabrooks and Wallin (2010). Before research findings can improve teaching and learning of secondary school mathematics, there is the need to find out firstly, if the end users (mathematics teachers) have access to these research reports or not.

\subsection{Statement of the Problem}

The basis for a research is to solve relevant problems in human endeavours rather than taking idle curiosity in studying. Results of our students at their final school certificate examinations do not justify the research efforts taking place in our tertiary institutions. It does appear as if the secondary school teachers of mathematics are not conscious of the fact that a discovery of research findings could make the students better off in their learning outcomes. Thus, this study attempted finding out the level of their awareness and implementation of research findings in mathematics teaching.

\subsection{Research Questions}

The following research questions have been raised to guide the study.

1. To what extent are the mathematics teachers aware of research findings in some aspects of mathematics education?

2. To what extent do mathematics teachers implement research findings in mathematics education?

\subsection{Hypotheses}

H01: There is no significant difference between mathematics teachers' educational qualification and extent of awareness on research findings in mathematics education.

H02: There is no significant difference between teachers' qualification in Mathematics and extent of implementation of research findings in mathematics education.

\section{$2 \quad$ Methodology}

The study adopted a descriptive study of the expo-facto type. The population comprised mathematics teachers in Ibadan Metropolitan area of Nigeria. Ibadan 
is the largest city in West Africa sub-region especially in expanse and coverage. There are five urban local government areas and six semi-urban local government areas in the less-city. Two Local government areas were randomly selected out of the eleven local government areas in Ibadan Metropolitan area. One local government area was randomly elected from each of the strata identified above. Public (those owned by the government) and private owned secondary schools were randomly selected based on willingness of the school to take part in the study. A total of 132 Mathematics teachers were purposively selected from the 22 participating schools. The two instruments used for data collection are Mathematics Teachers' Awareness of Research Findings Questionnaire (MTARF) and Mathematics Teachers Implementation of Research Findings Questionnaire (MTIRF). MTARF and MTIRF are self-designed instruments with 9 items each relating to possible research areas in mathematics education. MTARF is on a 4-point scale rating (1 to 4) the extent of measure of the attribute concerned while MTIRF was on a 3-point rating scale. MTARF was to solicit information on mathematics teachers' awareness on these areas of research findings in mathematics education while MTIRF solicited information on the extent to which the teachers of mathematics made use of these research findings. These 2 instruments were pilot tested on 19 secondary school mathematics teachers and validated. The coefficients of reliability of MTARF was $r=0.9$ while that of MTIRF was 0.8 . The data was analysed using descriptive statistics, independent t-test and analysis of variance (ANOVA) at 0.05 level of significant.

\section{$3 \quad$ Findings and Discussions}

Research Question 1: To what extent are the Mathematics teachers aware of research findings in Mathematics Education? 
Table 1: Awareness about Research Findings in Mathematics Education

\begin{tabular}{|c|c|c|c|c|c|c|c|}
\hline Research Areas & $\begin{array}{ll}\text { No Extent } \\
(1)\end{array}$ & $\begin{array}{l}\text { Little } \\
\text { Extent (2) }\end{array}$ & $\begin{array}{l}\text { Moderate } \\
\text { Extent (3) }\end{array}$ & $\begin{array}{l}\text { Great } \\
\text { Extent (4) }\end{array}$ & Mean & $\begin{array}{l}\text { Std. } \\
\text { Dev. }\end{array}$ & Decision \\
\hline Mathematics Testing and Assessment & $9(6.8)$ & $34(25.8)$ & $56(42.4)$ & $25(18.9$ & 2.78 & .851 & Accept \\
\hline Mathematics Teaching methods and strategies & $9(6.8)$ & $28(21.2)$ & $57(43.22)$ & $27(20.5)$ & 2.84 & .856 & Accept \\
\hline Students' learning approach in mathematics & $6(4.5)$ & $25(18.9)$ & $55(41.7$ & $32(24.2)$ & 2.96 & .831 & Accept \\
\hline Instructional materials in the teaching of mathematics & $10(7.6)$ & 25 (18.9) & $52(39.4)$ & $36(27.3)$ & 2.93 & .907 & Accept \\
\hline Mathematics Textbooks & $9(6.8)$ & $21(15.9)$ & $44(33.3)$ & $42(31.8)$ & 3.03 & .927 & Accept \\
\hline Social Media and the teaching and learning of mathematics & $14(10.6)$ & $32(24.2)$ & $47(35.6)$ & $30(22.7)$ & 2.76 & .952 & Accept \\
\hline Classroom environment and mathematics learning & $14(10.6)$ & $19(14.4)$ & $58(43.9)$ & $32(24.2)$ & 2.88 & ‘928 & Accept \\
\hline Teachers' factors in the teaching and learning of mathematics & $15(11.4)$ & $21(15.9$ & $59(44.7)$ & $28(21.2)$ & 2.81 & .926 & Accept \\
\hline $\begin{array}{l}\text { Research reports on school leadership and mathematics learning } \\
\text { outcomes }\end{array}$ & 15 (11.4) & $32(24.2)$ & 49 (37.1) & $27(20.5)$ & 2.72 & .945 & Accept \\
\hline
\end{tabular}


The study considered nine possible areas of research in mathematics education from which the mathematics teachers can derive results for teaching improvement. These areas are on teaching methods and strategies, research on students' learning approach in mathematics, testing and assessment in mathematics, instructional materials in teaching, research on mathematics textbooks, social media, classroom environment, teachers' factors in teaching and learning of mathematics, school leadership and mathematics teaching/learning.

Table 1 shows the level of awareness of secondary school mathematics teachers on these areas of research in mathematics education. The teachers indicated their level of awareness of research findings in mathematics education on a 4-point scale as: no awareness, little awareness, moderate extent of awareness and awareness to a great extent, rated from 1 to 4 respectively. On this scale, a mean score of 2.5 has been taken as benchmark for decision on the level of awareness. Mean value above 2.5 is taken to be in favour of awareness of the aspect of research while mean below it is taken as low level of awareness. All the nine research areas in mathematics are well above 2.5. Item 5 which bothers on research findings in the area of mathematics textbook in mathematics teaching has the highest mean (3.03) while research area on school leadership and mathematics achievement has the lowest mean (2.72). It suffices to say that the mathematics teachers are moderately aware of the research areas in mathematics education. Before this study, the researcher had wrongly assumed that the mathematics teachers might not be very much aware of research findings in mathematics education to this extent. The study has proved this assertion wrong. The teachers are aware of research findings in mathematics education.

Research Question 2: To what extent do the Mathematics teachers implement research findings in Mathematics Education? 
Makerere Journal of Higher Education

Table 2: Implementation of Research Findings in Mathematics Education

\begin{tabular}{|c|c|c|c|c|c|}
\hline Research Findings in the area of: & Not Heard (0) & Heard but not Used (1) & Heard and Used (2) & Mean & Std. Dev. \\
\hline Mathematics Testing and Assessment & $6(4.5)$ & $13(9.8)$ & $104(78.8)$ & 1.80 & .511 \\
\hline Mathematics Teaching methods and strategies & $5(3.8)$ & $14(10.8)$ & $102(77.3)$ & 1.80 & .494 \\
\hline Students' learning approach in mathematics & $6(4.5)$ & $19(14.4)$ & $97(73,5)$ & 1.75 & .539 \\
\hline Instructional materials in the teaching of mathematics & $3(2.3)$ & $14(10.6)$ & $106(80.3)$ & 1.84 & .432 \\
\hline Mathematics Textbooks & $3(2.3)$ & $16(12.1)$ & $105(79.5)$ & 1.82 & .443 \\
\hline $\begin{array}{l}\text { Social Media and the teaching and learning of } \\
\text { mathematics }\end{array}$ & $7(5.3)$ & $34(25.8)$ & $82(62.1)$ & 1.61 & .596 \\
\hline Classroom environment and mathematics learning & $9(6.8)$ & $15(11.4)$ & $10(76.5)$ & 1.74 & .584 \\
\hline $\begin{array}{l}\text { Teachers' factors in the teaching and learning of } \\
\text { mathematics }\end{array}$ & $12(9.1)$ & $18(13.6)$ & $95(72.0)$ & 1.66 & .647 \\
\hline $\begin{array}{l}\text { Research reports on school leadership and mathematics } \\
\text { achievement }\end{array}$ & $10(7.6)$ & $35(26.5)$ & 79 (59.8) & 1.56 & .641 \\
\hline
\end{tabular}


The fact that the teachers are aware of these areas of research findings does not tantamount to the same level of application in classroom practices. Thus, the justification for research question 2 . Table 2 is an expression of the extent to which the mathematics teachers apply the research reports on these nine research areas in mathematics education. Their responses are on a 3-point scale rated as 0,1 and 2. If they have not heard about this research findings $(0)$, if they have heard about this research findings but they have not implemented it in their classroom teaching (1) and if they have heard and used the research findings in this area (2). A conclusion on an item is made by setting a benchmark of 1.25 , so that mean above it will be taken as haven heard and used and below is not used. All the mean expressions on these items are quite above 1.5. The highest mean ((1.84) use of the research findings is on instructional materials in the teaching of mathematics (item4) while the least mean (1.56) is on research reports on school leadership and mathematics achievement. This could mean that research reports on the area of instructional materials is popular or that it is taken as of paramount importance. There are expressions on research findings that reported the importance of instructional materials in teaching. This includes the study of Afolabi and Adeleke (2010) which talks about the availability and utilisation of instructional materials in the teaching of mathematics in the secondary school.

H01: There is no significant difference between mathematics teachers' educational qualifications and their level of awareness of research findings in mathematics education.

Table 3: Qualifications in Mathematics and Awareness about Research Findings in Mathematics Education

\begin{tabular}{llllll}
\hline & Sum of Squares & Df & Mean Square & F & Sig. \\
\hline Between Group & 13.170 & 26 & .507 & .835 & .690 \\
Within Group & 45.497 & 75 & .609 & & \\
Total & 58.667 & 101 & & & \\
\hline
\end{tabular}

The mathematics teachers' educational qualification was captured under 5 categories. There were NCE/OND holder $(6 ; 4.5 \%)$, Bachelor Degree/HND holder (87; 65.9\%), Masters Degree (26; 19.7\%), Ph.D. (1; 0.8\%), others (5, $3.8 \%$ ). The report of ANOVA is shown in Table 3. The findings shows that there is no significant difference between mathematics teachers' educational qualifications and their level of awareness of research findings in mathematics education, $(\mathrm{F}=.835 ; \mathrm{p}=.690>.05)$. The null hypothesis is not rejected. It is possible to expect a significant difference between these two variables due to diverse categories of qualifications that span over a high range of values, but this is not so. Experience could have been responsible for teachers' awareness even 
if they are of a lower qualification. The possibilities of in-service trainings in workshops and seminars are avenues for exposure to research findings.

H02: There is no significant difference between teachers' qualifications in Mathematics and extent of implementation of research findings in mathematics education.

Table 4: ANOVA in Implementation of Research Findings in Mathematics Education

\begin{tabular}{|c|c|c|c|c|c|c|}
\hline Research areas & & $\begin{array}{l}\text { Sum of } \\
\text { Square }\end{array}$ & Df & $\begin{array}{l}\text { Mean } \\
\text { square }\end{array}$ & $\mathrm{F}$ & Sig \\
\hline \multirow{3}{*}{$\begin{array}{l}\text { Mathematics Testing and } \\
\text { Assessment }\end{array}$} & Between Groups & 2.563 & 4 & .641 & \multirow[t]{3}{*}{2.485} & \multirow[t]{3}{*}{.048} \\
\hline & Within Groups & 29.141 & 113 & .258 & & \\
\hline & Total & 31.703 & 117 & & & \\
\hline \multirow{3}{*}{$\begin{array}{l}\text { Mathematics Teaching } \\
\text { methods and strategies }\end{array}$} & Between Groups & 3.849 & 4 & .962 & \multirow[t]{3}{*}{4.241} & \multirow[t]{3}{*}{.003} \\
\hline & Within Groups & 25.186 & 111 & .227 & & \\
\hline & Total & 29.034 & 115 & & & \\
\hline \multirow{3}{*}{$\begin{array}{l}\text { Students' learning } \\
\text { approach in mathematics }\end{array}$} & Between Groups & 1.487 & 4 & .372 & \multirow[t]{3}{*}{1.251} & \multirow[t]{3}{*}{.294} \\
\hline & Within Groups & 33.299 & 112 & .297 & & \\
\hline & Total & 34.786 & 116 & & & \\
\hline \multirow{3}{*}{$\begin{array}{l}\text { Instructional materials in } \\
\text { the teaching of } \\
\text { mathematics }\end{array}$} & Between Groups & 1.028 & 4 & .257 & \multirow[t]{3}{*}{1.345} & \multirow[t]{3}{*}{.258} \\
\hline & Within Groups & 21.582 & 113 & .191 & & \\
\hline & Total & 22.61 & 117 & & & \\
\hline \multirow[t]{3}{*}{ Mathematics Textbooks } & Between Groups & 2.968 & 4 & .742 & \multirow[t]{3}{*}{4.034} & \multirow[t]{3}{*}{.004} \\
\hline & Within Groups & 20.965 & 114 & .184 & & \\
\hline & Total & 23.933 & 118 & & & \\
\hline \multirow{3}{*}{$\begin{array}{l}\text { Social Media and the } \\
\text { teaching and learning of } \\
\text { mathematics }\end{array}$} & Between Groups & 5.428 & 4 & 1.357 & \multirow[t]{3}{*}{4.140} & \multirow[t]{3}{*}{.004} \\
\hline & Within Groups & 37.046 & 113 & .328 & & \\
\hline & Total & 42.475 & 117 & & & \\
\hline \multirow{3}{*}{$\begin{array}{l}\text { Classroom environment } \\
\text { and Mathematics learning }\end{array}$} & Between Groups & 3.036 & 4 & .759 & \multirow[t]{3}{*}{2.245} & \multirow[t]{3}{*}{.068} \\
\hline & Within Groups & 38.889 & 115 & .338 & & \\
\hline & Total & 41.925 & 119 & & & \\
\hline \multirow{3}{*}{$\begin{array}{l}\text { Teachers' factors in the } \\
\text { teaching and learning of } \\
\text { mathematics }\end{array}$} & Between Groups & 4.121 & 4 & 1.030 & \multirow[t]{3}{*}{2.511} & \multirow[t]{3}{*}{.046} \\
\hline & Within Groups & 47.179 & 115 & .410 & & \\
\hline & Total & 51.3 & 119 & & & \\
\hline \multirow{3}{*}{$\begin{array}{l}\text { Research reports on } \\
\text { school leadership and } \\
\text { mathematics } \\
\text { achievement }\end{array}$} & Between Groups & 3.473 & 4 & .868 & \multirow[t]{3}{*}{2.151} & \multirow[t]{3}{*}{.079} \\
\hline & Within Groups & 46.023 & 114 & .404 & & \\
\hline & Total & 49.496 & 118 & & & \\
\hline
\end{tabular}

This hypothesis became necessary because not all the teachers have qualification in mathematics even though they teach mathematics. Some of them may have physical or mathematical sciences or engineering qualifications. This is the 
peculiarity of a developing country. It is because of dearth of professionally trained mathematics teachers. The nine areas of research in mathematics education have been tested (table 4). This has been done to observe which research area will make a significant difference with teachers' qualifications. The qualification examined here is specifically to those who studied mathematics in one or more of these levels; 1) NCE; (2) B.Sc.।B.A.; (3) B.Sc. (Ed)\B.A.(Ed); (4) Higher Degree;(5) others. The implementation of research findings in each area of research in mathematics education shown above have been tested against teachers' qualification in mathematics. There exist a significant difference between teachers' qualifications and the implementation of research findings in the area of1) mathematics teaching and testing $(\mathrm{F}=2.485, \mathrm{p}=.048)$ 2)mathematics teaching methods and strategies, $(\mathrm{F}=4.241 ; \mathrm{p}=.003), 3)$ mathematics textbooks $(\mathrm{F}=4.034 ; \mathrm{p}=.004), 4)$ social media and the teaching and learning of mathematics $(\mathrm{F}=4.140 ; \mathrm{p}=.004), 5)$ teacher factors in the teaching and learning of mathematics $(\mathrm{F}=2.511 ; \mathrm{p}=.046)$. Research findings in the areas of student learning approach, instructional materials, classroom environment and research reports on school leadership had no significant difference with teachers' qualifications in mathematics.

It is concluded that the poor performances of our students in their final school certificate examination in mathematics are not caused by teachers' lack of awareness and inability to implement research findings in teaching. Other factors could have caused the poor performances. Some other factors outside research report implementation are responsible for their performance.

Further research should cover more likely barriers to research report implementation. Causes of students' poor performance should be researched further in other areas. Stakeholders in the scaffold of organization of schools must give attention to activities that can channel research findings to mathematics teachers. Mathematics teachers should be motivated to explore new strategies and given free hands to implement new ideas in their classroom practices.

\section{References}

Abimbade, A., Afolabi, S. S. (2012). A study of pedagogical approaches of mathematics teaching in south-western states of Nigeria. International Journal of Asian Social Science. 2 (8), 1182-1192.

Afolabi, S. S., Animasahun, I. A. (2013). Mathematics Textbook Attributes as a Predictor of Students' Attitude to Mathematics. European Scientific Journal. 9 (9), 159-170. 
Afolabi, S. S., Adeleke, J. O. (2010). Assessment of Resources and Instructional Material Status in the Teaching of Mathematics in South-western Nigeria. European Journal of Scientific Research. 43 (3), 406-410.

Afolabi, S. S. (2010). Mathematics Teaching in South-western Nigeria: Criteria for Pedagogical Options. International Journal of Contemporary Issues in Education. Special Edition, 2010. pp. 322-328.

Afolabi, S. S. (2015). Gender Representation in Mathematics Textbooks as Correlate of Students' Learning Outcomes in Mathematics. Journal of the Nigerian Academy of Education (JONAED). Vol. 11 no. 1, p174-185.

Afolabi, S. S. (2017). Practical Approach to Teaching and Assessment in Mathematics. African Journal of Theory and Practice of Educational Research. 4, pp. 125-138.

Do, T. L. (2010). Gender stereotypes in school textbooks. Available at; http://www.results.org/website/article.asp?id=2017.

Douville, P., Pugalee, D. K. (2003). Investigating the relationship between mental imaging and mathematical problem solving. Proceedings of the international conference of Mathematics Education into the $21^{\text {st }}$ century project, September 2003. Ed. Brno. Czech Republic: 62-67.

Douville, P. (2004). Use mental Imagery Across the curriculum: Preventing school failure. Preventing School Failure: Alternative Education for Children and Youth. 49 (1), 36-39.

Durodola, P. O. (2017). Effects of Mobile Technology on Students' learning Outcomes in Mathematics. Unpublished dissertation. National Open University of Nigeria.

EduBirdie (2016). The Best Essay Writing. Available at https://ca.edubirdie.com/blog/what-is-the-purpose-of-a-research-paper.

Downloaded on22/8/18.

Funk, S. G, Champagne, M. T, Wiese, R. A, Tornquist E. M. (1991). The Barriers to Research Utilization Scale. Applied Nursing Research. 1991.4 (1), p39-45.

Gharbavi, A., Mousavi, S. A. (2012). A content analysis of textbooks: Investigating gender bias as a social prominence in Iranian high school English textbooks. English Linguistics Research 1(1), p. 42-49.

Johansson, M. (2003). Textbooks in Mathematics education: a study of textbooks as the potentially implemented curriculum. Licentiate Thesis. Department of Mathematics. Lulea University of Technology.

Kajermo, K. N., Bostrom, A. M, Thompson, D. S. Hutchinson, A. M, Estabrooks, C. A. Wallin, L. (2010). The BARRIERS scale -- the barriers to research utilization scale: A systematic review. Implementation Science. Vol 5, no 32. https://doi.org/10.1186/1748-5908-5-32.

M. Libraries (nd). The Purpose of Research Writing. M. Libraries Publishing. University of Minnesota. Downloaded on 22/8/18 Available 
https://open.lib.umn.edu/writingforsuccess/chapter/11-1-the-purpose-ofresearch-writing/.

Ogunbiyi, O. (2004). New challenges in the methodologies of teaching: A case for in- service programme for school teachers. Teachers' mandate on education and social development in Nigeria. D.F. Elaturoti and A. Babarinde Eds. Nigeria Stirling-Horden publishers.

Omisakin, L (2018). Relationship among Administrators' Leadership Style, School Culture and Students' Achievement in Mathematics. Unpublished dissertation. National Open University of Nigeria. 